\title{
The Effect of Mineral-Based Mixtures Containing Coal Fly Ash and Sewage Sludge on Chlorophyll Fluorescence and Selected Morphological Parameters of Deciduous and Coniferous Trees
}

\author{
Agnieszka Bęś *(D), Łukasz Sikorski and Krzysztof Szreder \\ Department of Chemistry, Faculty of Agriculture and Forestry, University of Warmia and Mazury in Olsztyn, \\ 10-957 Olsztyn, Poland; lukasz.sikorski@uwm.edu.pl (Ł.S.); krzysztof.szreder@uwm.edu.pl (K.S.) \\ * Correspondence: agnieszka.bes@uwm.edu.pl; Tel.: +48-89-523-33-36
}

check for

updates

Citation: Bẹś, A.; Sikorski, Ł.; Szreder, K. The Effect of

Mineral-Based Mixtures Containing Coal Fly Ash and Sewage Sludge on Chlorophyll Fluorescence and Selected Morphological Parameters of Deciduous and Coniferous Trees. Minerals 2021, 11, 778. https:// doi.org/10.3390/min11070778

Academic Editor: Maria Economou-Eliopoulos

Received: 31 May 2021 Accepted: 16 July 2021 Published: 18 July 2021

Publisher's Note: MDPI stays neutral with regard to jurisdictional claims in published maps and institutional affiliations.

Copyright: (c) 2021 by the authors. Licensee MDPI, Basel, Switzerland. This article is an open access article distributed under the terms and conditions of the Creative Commons Attribution (CC BY) license (https:// creativecommons.org/licenses/by/ $4.0 /)$.

\begin{abstract}
Coal fly ash (CFA), which is generated in huge quantities in coal-fired power plants, is a problem worldwide. Mixtures with ash and sewage sludge alter morphological and biochemical characteristics of plants. In this experiment, the response of pine, spruce, beech and alder growing for four years to mineral mixtures based on coal fly ash and high salinity sewage sludge (SS) was studied. The four-year experiment determined the chlorophyll a fluorescence of the tested plants, their height and yield, the salinity level of the tested mixtures and their phytotoxicity. Mixtures of coal ash with sewage sludge proved to be more beneficial to plants than their separate application. After four years, among the studied species, the highest increase in height and biomass was recorded for European alder and Scots pine. These species were also characterized by high photosynthetic indices. Mixtures containing 29\% SS created optimal conditions for the development of the studied tree species. Grey alder and ponderosa pine can be recommended for reclamation of degraded areas where CFA and SS mixtures are used.
\end{abstract}

Keywords: Scots pine; European beech; European alder; Norway spruce; biomass yield; height; chlorophyll a; salinity

\section{Introduction}

Trees are recommended for land reclamation programs in degraded areas because they store large amounts of biomass, which increases their tolerance to high pollution levels [1]. In the literature, there is a general scarcity of long-term studies investigating trees that grow on substrates containing mixtures of coal fly ash (CFA) and sewage sludge (SS). Energy production is on the rise around the world, and it generates large amounts of fly ash each year. The combustion of coal and combined heat in power plants contribute to fly ash emissions in the environment [2,3]. In Poland, the production of CFA reached 2.42 million tons in 2018. The global fly ash output is estimated at 2222 million tons per year. Sewage sludge from municipal wastewater treatment plants is landfilled, incinerated or used in land reclamation. Around 1.05 million tons of sewage sludge dry matter was produced in Poland in 2018 [4]. The use of sewage sludge and fly ash in reclamation minimizes the adverse effects of their storage and contributes to a circular economy.

Coal fly ash is produced in immense quantities in coal-fired power plants, and it constitutes a significant problem around the world [5]. Landfilling of fly ash from coal combustion poses a health risk and contributes to air, soil and water pollution by releasing leached heavy metals into the environment [6-8]. According to Ram and Masto [5], Krzaklewski et al. [9] and Antonkiewicz et al. [10], CFA has considerable potential for the reclamation of degraded areas, fallow land, defunct mining sites and landfills. Coal fly ash improves the physical, chemical and biological properties of soil. In some cases, however, trace minerals and soluble salts can be released from CFA to the soil-plant-human continuum. Waste from coal combustion is deficient in nitrogen and highly susceptible to 
compaction; it is highly soluble in the air-water interface, has a strongly alkaline $\mathrm{pH}$ and high salt content [11]. Salt stress is the main inhibitor of plant growth and crop yields. The mechanism responsible for stress responses in plants has to be understood to develop new methods for increasing crops' resistance to salinity [3].

The rapid progress of urbanization also generates large quantities of sewage sludge from treated municipal and industrial wastewater. Sewage sludge contains organic pollutants that emit unpleasant odors, dangerous pathogens and toxins, which pose an environmental threat. Various processing methods and techniques are deployed to neutralize sewage sludge [12-14]. Sewage sludge can be incinerated, landfilled, sanitized during anaerobic digestion and composting, used in agriculture or biochar production by pyrolysis $[15,16]$. Sewage sludge is a valuable source of macronutrients and micronutrients, which can replace mineral fertilizers in agriculture $[17,18]$. Due to its high organic matter and nutrient content, sewage sludge is also suitable for the reclamation of agricultural land $[3,9]$.

Coal combustion by-products (ashes) contain heavy metals and low concentrations of essential nutrients, which significantly limits their applicability in agriculture. Low nutrient levels, in particular nitrogen, phosphorus and potassium, can be easily compensated for through the addition of sewage sludge [19]. The application of anaerobically digested sewage sludge and CFA in land reclamation is an economical and effective waste reuse strategy. However, the heavy metal content of sewage sludge and CFA should be analyzed before these materials are used as substrates for reclamation [20,21]. Municipal sewage sludge are abundant in nutrients and highly suitable for the biological reclamation of degraded areas [22-24]. Various technological and biological methods are used to stabilize and secure sites where coal combustion and flotation waste, mining spoils and municipal waste are landfilled. The ground is covered with an insulating layer, and turf grass is sown or trees are planted [25]. Pioneer tree species can be planted initially, and species with higher environmental requirements can be introduced when soil conditions have improved and soil-forming processes have been initiated [9].

Higher plants that produce large amounts of biomass and are resistant to high pollution levels are used in land reclamation [26]. These plants are capable of growing in contaminated environments. Trees are particularly recommended for reclamation programs because they sequester large amounts of carbon [27] and are resistant to both biotic and abiotic stressors [28]. Tree species have to be carefully selected for biological reclamation of degraded areas [29,30]. Tree responses to drought [31-34] and heavy metal contamination [35-38] have been extensively described in the literature. However, there is a general scarcity of long-term studies investigating the development of higher plants growing on substrates containing mixtures of CFA and SS.

It is well known that the addition of CFA and SS to mineral-based mixtures modifies the morphological and biochemical properties of plants. However, the responses of Scotts pine, Norway spruce, European beech and European alder to mineral-based mixtures enhanced with CFA and SS with high salinity content have never been investigated. Therefore, the aim of this study was to evaluate the effects of mineral-based mixtures containing CFA and SS on the analyzed tree species and to determine which species is most resistant to salinity stress, capable of adapting and growing on CFA and SS substrates and producing large amounts of biomass. The suitability of mineral-based mixtures containing CFA and SS as substrates for landfill reclamation was analyzed by evaluating their impact on coniferous and deciduous trees. Chlorophyll a fluorescence, tree height, biomass yield, salinity levels in the analyzed substrates and their phytotoxicity were determined in a four-year experiment.

\section{Materials and Methods}

\subsection{Experimental Design}

A four-year greenhouse experiment was conducted between 2014 and 2017 in the Experimental Station of the University of Warmia and Mazury in Olsztyn, Poland. Mineral- 
based mixtures were prepared by combining CFA with SS. Sewage sludge was obtained from a municipal wastewater treatment plant in Dobre Miasto (Region of Warmia and Mazury, Poland), and CFA was acquired from a power plant operated by Michelin Polska S.A. in Olsztyn (Region of Warmia and Mazury, Poland). The parameters of SS and CFA are presented in Table 1. A chemical composition analysis of the evaluated waste products revealed that heavy metal concentrations did not exceed safe levels; therefore, both materials could be added to soil and used in agriculture and land reclamation. The evaluated samples were characterized by high salinity levels (measured based on electrical conductivity, EC). Therefore, salt content was determined in each experimental mixture containing CFA and SS.

Table 1. Selected physicochemical parameters of sewage sludge, coal fly ash and control soil in the experiment.

\begin{tabular}{cccc}
\hline \multirow{2}{*}{ Parameter } & \multicolumn{3}{c}{ Measured Value } \\
\cline { 2 - 4 } & Sewage Sludge (SS) & Coal Fly Ash (CFA) & Control Soil \\
\hline $\mathrm{pH}$ H2O & 7.21 & 9.97 & 7.72 \\
$\mathrm{Mn}(\mathrm{mg} / \mathrm{kg})$ & 310.00 & 274.00 & 69.32 \\
$\mathrm{Zn}(\mathrm{mg} / \mathrm{kg})$ & 516.00 & 52.7 & 8.85 \\
$\mathrm{Cu}(\mathrm{mg} / \mathrm{kg})$ & 114.0 & 25.00 & 1.54 \\
$\mathrm{Cd}(\mathrm{mg} / \mathrm{kg})$ & 3.40 & 0.40 & 0.08 \\
$\mathrm{~Pb}(\mathrm{mg} / \mathrm{kg})$ & 34.7 & 19.1 & 4.97 \\
$\mathrm{Cr}(\mathrm{mg} / \mathrm{kg})$ & 18.6 & 21.1 & 14.22 \\
Electrical conductivity (S/m) & 0.23 & 0.714 & 0.02 \\
$\mathrm{~N}-$ total $(\%)$ & 4.91 & 0.11 & 0.141 \\
$\mathrm{C}(\%)$ & 42.74 & 10.19 & 1.84 \\
Granulometric composition & & & \\
$(\%$ fraction content) & - & - & 72.21 \\
$2-0.05 \mathrm{~mm}$ & - & - & 15.13 \\
$0.05-0.02 \mathrm{~mm}$ & - & - & 1.30 \\
$0.02-0.002 \mathrm{~mm}$ & - & - & \\
$<0.002 \mathrm{~mm}$ & &
\end{tabular}

The prepared mixtures were mineralized in nitric acid $\left(\mathrm{HNO}_{3}, \mathrm{AR}\right.$ grade) with a concentration of $1.40 \mathrm{~g} \cdot \mathrm{cm}^{-3}$ in a Milestone Star D microwave oven. The concentrations of $\mathrm{Mn}, \mathrm{Cr}, \mathrm{Cd}, \mathrm{Pb}, \mathrm{Zn}$ and $\mathrm{Cu}$ in the extracts were determined by atomic absorption spectroscopy (AAS) in an air-acetylene flame with the use of the iCE-3000 analyzer (Thermo Scientific, Waltham, MA, USA). The measuring instruments were calibrated with certified Merck calibration standards. The $\mathrm{pH}$ of soil, CFA and SS samples was measured with a standard combination electrode and a $\mathrm{pH}$ meter (HI 221, Manufacturer, Abbr, USA) in water. All glass and polyethylene vessels were disinfected with $5 \mathrm{~mol} \cdot \mathrm{L}^{-1} \mathrm{HNO}_{3}$ for $24 \mathrm{~h}$, rinsed three times with distilled water and three times with deionized water before use. Measurements were performed in triplicate. Total nitrogen was determined by the Khiejdal method. Solid samples for total carbon content were analyzed with a Shimadzu TOC-VPN analyzer (Shimadzu Corporation, Kyoto, Japan). The method of measurement consists in heating the sample under UV light to convert the TC (total carbon) contained in the sample to carbon dioxide. The carbon dioxide flows along with the carrier gas $\left(\mathrm{O}_{2}-99.999 \%\right.$; Linde Gas, Danbury, CT, USA) through the dryer to the NDIR measuring cell. The analyzer measures the signal area of the carbon dioxide peak. From the area of the peak obtained, the TC concentration is calculated on the basis of the calibration curve.

The proportions of CFA and SS in the prepared mixtures are presented in Table 2. Coal fly ash was combined with sewage sludge, and the mixtures were stabilized in dark at room temperature for seven days. After seven days, the mixtures were placed in $7 \mathrm{~L}$ pots. The experiment was performed on one-year-old seedlings of Scots pine (Pinus sylvestris L.), Norway spruce (Picea abies), European beech (Fagus sylvatica L.) and European alder (Alnus glutinosa) acquired from the nursery of the Kudypy Forest Division (Regional 
Directorate of State Forests in Olsztyn, Poland). Seedlings were selected to ensure that all plants of a given species had similar height. The experiment was conducted in four replications. Five seedlings of the same species were planted per pot. Pots filled with light soil were the control. Soil for the experiment was obtained from non-contaminated agricultural land. The experiment had 120 pots in total.

Table 2. Composition of mineral-based mixtures.

\begin{tabular}{ccc}
\hline No of Mixture & Sewage Sludge (SS) [\%] & Coal Fly Ash (CFA) [\%] \\
\hline Control-soil (Control) & 0 & 0 \\
1 (0SS/100CFA) & 0 & 100 \\
2 (5SS/95FCA) & 5 & 95 \\
3 (9SS/91CFA) & 9 & 91 \\
$4(16 S S / 84$ CFA) & 16 & 84 \\
$5(29 S S / 71$ CFA) & 29 & 71 \\
\hline
\end{tabular}

In Europe, the geographic range of the European beech stretches from the norther part of the Iberian Peninsula, through France, Germany and Central Europe to the Balkans. European beech is one of the dominant tree species in forests in western and southern Poland. The species is highly resistant to soil acidification, and it grows on aerated and moist soils [39]. European beech occupies 6.0\% of total forest area in Poland [4], and it is one of the most resistant tree species in industrial regions. Horodecki and Jagodziński [40] analyzed nine tree species growing on an afforested spoil tip in Bełchatów and found that European beech was characterized by the slowest decomposition of organic matter accumulated in the ground cover. According to Krzaklewski [41], European beech adapts more slowly to soil-deficient habitats than other tree species, which is why it should be used as the main (target) species in soil reclamation projects.

European alder has high soil requirements, and it thrives on moist and fertile soils in flood zones. The species is used in the reclamation of industrial sites, spoil tips, landfill sites and fallow land. European alder is a fast-growing species. Its geographic range covers Europe, selected regions of Asia and north-western Africa. Members of the genus Alnus occupy $5.7 \%$ of total forest area in Poland, and European alder is the predominant species [4]. According to Jaworski [42], European alder is one of the fastest growing trees with an annual growth rate of up to $120 \mathrm{~cm}$. The species fixes atmospheric nitrogen through a symbiotic association with Actinobacteria. It decomposes ground cover with a $\mathrm{pH}$ of around 4.6, and it is resistant to drought [41]. Other species of the genus Alnus, including grey alder (Alnus incana (L.) Moench) and green alder (Alnus viridis (Chaix) Lam. et DC.), are also used in land reclamation. Grey alder and green alder are widely applied in the biological reclamation of fly ash landfill areas [43]. Alders are also planted in degraded areas for economic reasons because they fertilize soil for the future generations of target tree species [9].

Scots pine is the most popular species of coniferous trees in north-eastern Europe [44], and it occupies more than $60 \%$ of total forest area in Poland [4]. Scots pine has low soil requirements, which makes it the ideal species for land reclamation, remediation and afforestation in Central Europe [25,36]. Scots pine is particularly sensitive to high concentrations of $\mathrm{SO}_{2}$ and $\mathrm{NO}_{\mathrm{x}}$ in ambient air. The popularity of Scots pine increased in the early 1990s when $\mathrm{SO}_{2}$ emissions decreased, and the species was planted mainly on spoil tips in open-pit mines [41]. Chodak [45] reported that in the group of tree species used in forest reclamation programs, Scots pine is characterized by lowest adaptability to the chemical and microbiological properties of industrial soils. Scots pines planted in former mining areas in East Germany were sensitive to the Heterbasidion annosum pathogen, which infested entire tree stands aged 17 to 20 years [46]. The adaptability of Scots pines to industrial soils in defunct mines was also investigated in Poland [47].

Norway spruce (Picea abies (L.) H. Karst) occupies around 5.8\% of the total forest area in Poland [4]. The species is sensitive to ozone, sulfur dioxide and hydrogen fluo- 
ride [42]. In the 1980s, a massive decline in Norway spruce stands in industrial sites in the Western Sudetes was caused by sulfur dioxide pollution (acid rain), which is why this species was not considered as suitable for the reclamation of mining areas [41]. Mauer and Mauerová [48] demonstrated that mycorrhization helper bacteria contributed to the successful establishment of Norway spruce seedlings in nutrient-deficient non-forest soils and industrial areas. Norway spruce is one of the most important coniferous tree species in Europe. It grows in the continental climate of Central and Northern Europe. In Central Europe, it is encountered mainly in mountainous regions. Norway spruce covers around $6 \%$ of the total forest area in Poland. The species has moderate soil requirements, and it is encountered both on limestone mountains and calcium-deficient soils. It is recommended for the reclamation of degraded areas but not as the dominant tree species.

The moisture content of mineral-based mixtures in pots was maintained at $75 \%$ of field water capacity during the entire experiment. Moisture content was measured with a timedomain reflectometry FOM/mts probe (Institute of Agrophysics of the Polish Academy of Sciences in Lublin, Poland). The pots were kept in a greenhouse during the growing season (April to October), and they were stored outdoors under natural conditions between November and March. The experimental years were characterized by varied weather conditions. The mean annual precipitation was determined at $600 \mathrm{~mm}$. The mean air temperature was estimated at $18{ }^{\circ} \mathrm{C}$ in July and $-4{ }^{\circ} \mathrm{C}$ in January, and the mean annual temperature approximated $7.6^{\circ} \mathrm{C}$. On average, there were 160 rainy days, 140 days with sub-zero temperature and 83 days with snow cover. The prevailing wind direction was southwest and west.

\subsection{Phytotoxicity Test}

After seven days of incubation, CFA and SS mixtures were subjected to the first phytotoxicity test. The test was conducted with the use of the Phytotoxkit, which evaluates acute toxicity based on seed germination and early plant growth. The Phytotoxkit test (Microbiotests Inc., Gent, Belgium) supports preliminary assessments of phytotoxicity in soil, sludges, sediments, composts, effluents for irrigation, chemical substances, pesticides and biocides relative to the control soil. The test measures the decrease in (or absence of) seed germination and root growth in selected higher plant species after three days of seed exposure in a given matrix, in comparison with the control soil. The control soil used in the present experiment was analogous to the artificial soil recommended by the OECD for soil toxicity tests involving invertebrates and by ISO for toxicity tests involving seeds. It was composed of sand $(85 \%)$, kaolin $(10 \%)$ and peat $(5 \%)$, and its $\mathrm{pH}$ was adjusted with calcium carbonate.

A standard phytotoxicity test involves seeds of selected plant species that are characterized by rapid germination and root growth to ensure that toxicity can be effectively analyzed after three days of incubation. In this experiment, the phytotoxicity test was performed on the seeds of Sinapis alba. The test is conducted in transparent PVC plates composed of two parts that can be tightly closed by a unique click system. The cover is flat, and the bottom part is separated into two compartments where samples of control and experimental soil are placed. Soil is saturated with water and spread across the entire compartment with a spatula. A black paper filter is placed over hydrated soil (control and experimental) in each compartment. Phytotoxkit high purity paper filters are cut to the shape of the test plate. Ten Sinapis alba seeds were placed on paper filter in each test plate. The seeds were spread at equal distance from the middle ridge separating the compartments. The plates were covered, locked, placed vertically in a cardboard holder and incubated in dark at a temperature of $25^{\circ} \mathrm{C}$ for three days. After $72 \mathrm{~h}$ of incubation, the plates with germinating plants were scanned. Root length was measured with the Image Tool 3.0 for Windows (UTHSCSA, San Antonio, TX, USA). Each test was conducted in triplicate. Each result was expressed as the mean of three replicates. 
The percentage inhibition of seed germination (GI) and root growth (RI) in each plant was calculated with the following formula:

$$
\mathrm{GI}(\mathrm{RI})=(\mathrm{A}-\mathrm{B}) / \mathrm{A} \times 100
$$

where:

A-seed germination and root length in control soil (OECD),

$\mathrm{B}$ - seed germination and root length in experimental soil (mineral-based mixture containing CFA and sewage sludge).

The second test was performed after the experiment on mineral-based mixtures containing CFA and sewage sludge mixtures sampled from each pot. Sinapis alba seeds were also sown in the second test.

\subsection{Biometric Parameters}

Plant height was measured with a ruler, to the nearest millimeter, from the base to the tip of the main shoot after planting and in April and September of each year. Biomass samples were collected from each pot after four years of plant growth. Aerial plant parts were harvested $5 \mathrm{~mm}$ above the soil surface and weighed.

\subsection{Moisture Content, Temperature and Salinity of Mixtures}

Moisture content, temperature and salinity were measured four times in each analyzed growing season with an FOM/mts field probe (Institute of Agrophysics of the Polish Academy of Sciences in Lublin, Poland). The above parameters were measured at the same time and in soil samples of identical volume. Each measurement was performed at three different points in a pot and at an appropriate distance from plant roots.

\subsection{Chlorophyll a Fluorescence}

The maximum potential quantum efficiency of Photosystem II (Fv/Fm) was measured on needles/leaves in the top half of new shoots with a Handy PEA chlorophyll fluorometer (Hansatech Instruments Ltd., King's Lynn, UK). The measurements were repeated on the same plants during the entire experiment. Chlorophyll fluorescence was measured twice in each growing season: at the turn of April and May (after full leaf emergence) and in August, which were referred to as spring and fall measurements, respectively. Photosynthetic efficiency was evaluated after $30 \mathrm{~min}$ of incubation in dark until reaction centers were photosynthesized and electron transfer was induced. Leaf/needle samples were covered with clips to quench the light phase of photosynthesis. The clips were placed in the central part of each leaf/needle. The measurements were performed on five leaves/needles selected from each plant. Fluorescence was induced across an area of $4 \mathrm{~mm}^{2}$ with light intensity of $3000 \mu \mathrm{mol} \cdot \mathrm{m}^{-2} \cdot \mathrm{s}^{-1}$. The maximum fluorescence (FM) was measured for 100 microseconds. Fluorescence kinetics was analyzed in Pocket PEA Plus V1.10 software (Hansatech Instruments Ltd.).

\subsection{Statistical Analysis}

Before the statistical analysis, the distribution of data in each independent group was checked for normality by the Shapiro-Wilk test, and the results were validated in the residual normality test. The assumption of homogeneity of variance was confirmed by Levene's test. A factorial ANOVA (F-test) was performed. The experimental factors were plant species, the composition of mineral-based mixtures and years of the study. Significant differences were determined by Tukey's test at $p=0.01$. Data were processed by two-way and three-way ANOVA and regression analysis.

The results of the phytotoxicity test, biomass yields, plant height, salinity and chlorophyll a fluorescence were processed in Statistica 13.3 software (StatSoft Inc., Tulsa, OK, USA, 2018). 


\section{Results}

\subsection{Phytotoxicity Test}

The phytotoxicity test of SS and CFA mixtures revealed significant differences in root length, depending on the type of additive and its proportions (\%) in the mixture. Differences were also noted in seed germination. The percentage inhibition of seed germination (GI) and root growth (RI) is presented in Figure 1. The highest GI (80\%) was observed on plates containing CFA only. Seed germination reached $60 \%(\mathrm{GI}=40 \%)$ in mixtures containing $95 \%, 91 \%$ and $84 \%$ of CFA, and the highest percentage of seeds $(90 \%, \mathrm{GI}=10 \%)$ germinated in mixture No. 5. In all analyzed mixtures, RI ranged from $92.94 \%$ to $48.24 \%$ relative to control (OECD soil). The results of the phytotoxicity test conducted after four years of phytoremediation demonstrated a reduction in soil salinity. The percentage of seeds that germinated on mineral-based mixtures containing CFA and SS ranged from $60.0 \%$ to $96.7 \%$, compared with OECD soil. After four years of phytoremediation, a minor decrease in root length $(1.57 \%-9.02 \%)$ was noted relative to OECD soil.
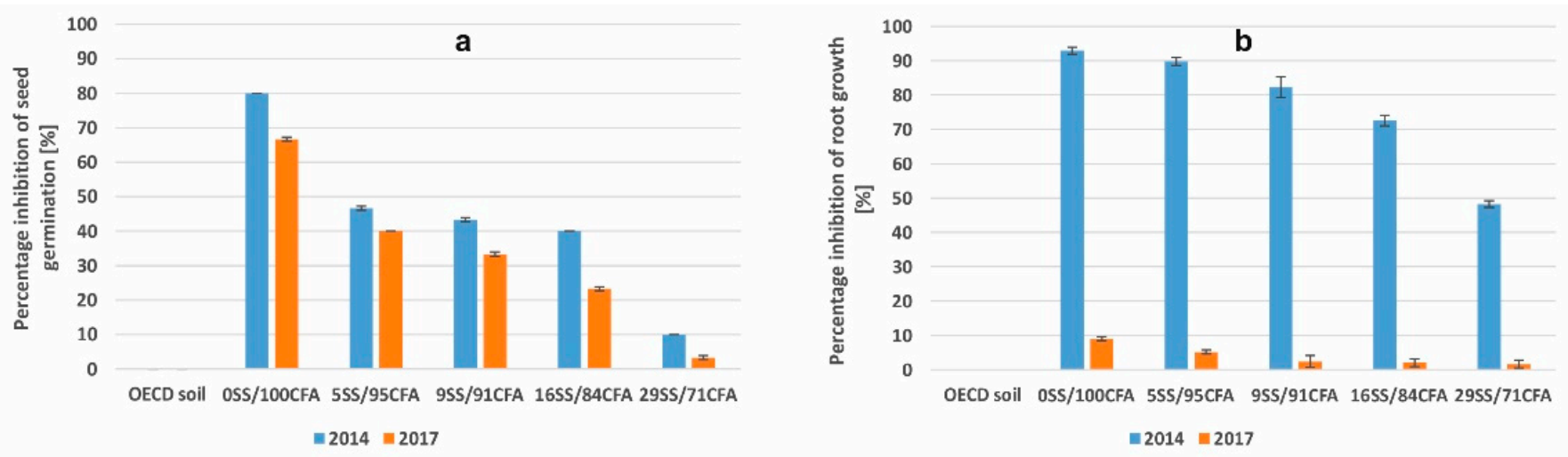

Figure 1. Percentage inhibition of seed germination (GI) and root growth (RI) in Sinapis alba; (a)—GI, (b)—RI. Data points represent the mean $\pm \mathrm{SD}, \mathrm{n}=3$.

\subsection{Biometric Properties and Biomass Yield}

An increase in height was observed in all plants grown on CFA and SS mixtures. The greatest increase was noted in European alder and Scots pine relative to control. Norway spruce and European beech seedlings grew at a slower rate. The smallest difference in seedling height was observed in the first year of the study. In successive years, significant differences in plant height were observed between the analyzed mixtures. The tallest seedlings were noted in mixture No. 5, which was most abundant in SS. Plants grown on CFA (mixture No. 1) were shortest (Figure 2). Seedling height was significantly correlated with the experimental years. Over the four years in the control soil, Scots pine grew in height by $517 \%$ and on the CFA and SS mixtures by $332 \%$ to $412 \%$. Control European beech plants grew 393\% taller, and plants growing on the analyzed mixtures from $150 \%$ to $195 \%$ taller. Large differences in height were noted for Norway sprouce. For four years in the control soil, Norway sprouce grew in height by $1172 \%$ and on the mineral-mased mixtures by $253 \%$ on average. The smallest differences in height compared to the control were noted for European alder. During the experiment in the control soil, European alder grew in height by $274 \%$ and on the mixture No. 5 by $240 \%$. 

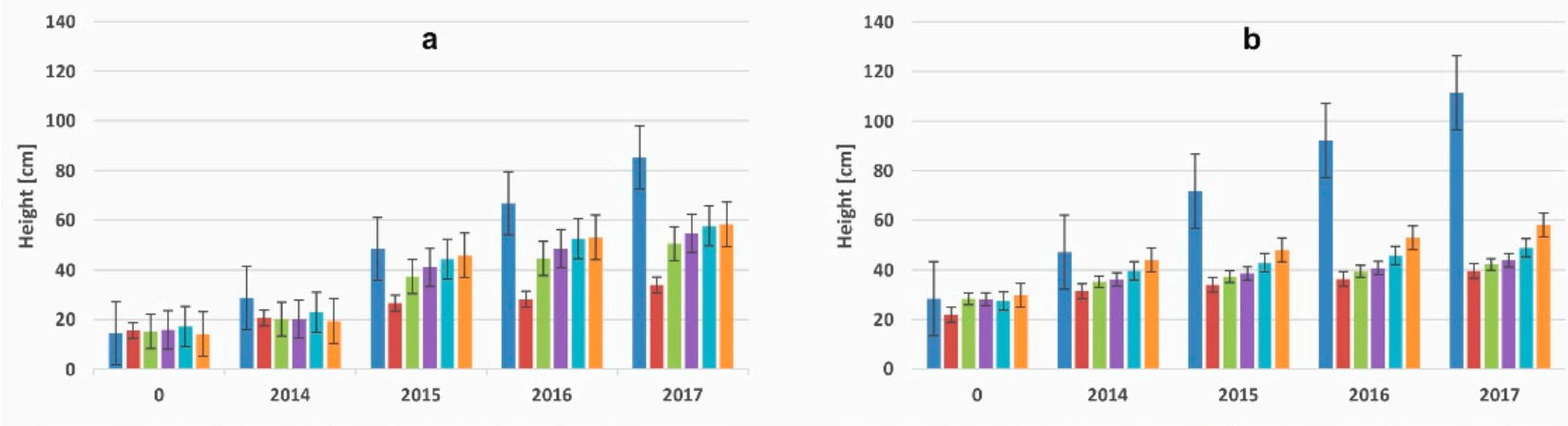

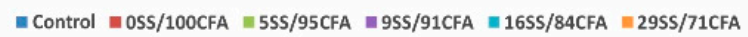

$\|$ Control $=$ OSS/100CFA $=5 S S / 95$ CFA $=95 S / 91$ CFA $=165 S / 84 C F A=295 S / 71 C F A$
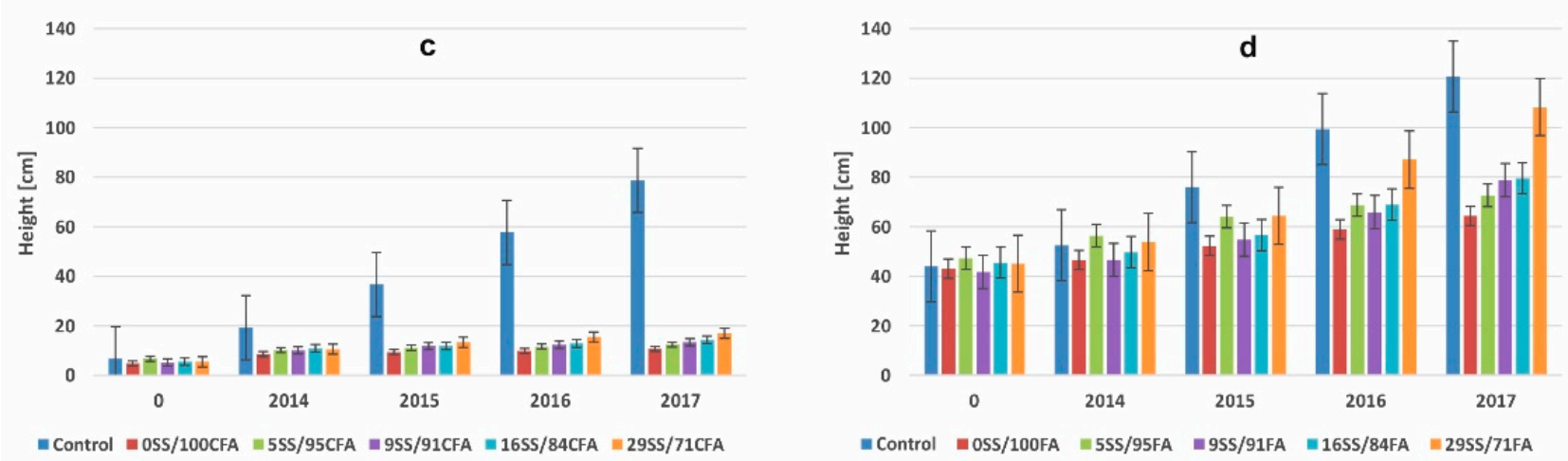

Figure 2. Average height (a) Scots pine; (b) European beech; (c) Norway spruce and (d) European alder. Data points represent the mean $\pm \mathrm{SD}, \mathrm{n}=4$.

The model based on a quadratic function with $\mathrm{R}^{2}>0.98$ best fit the experimental data. All model parameters for the height of European beech and Norway spruce seedlings were significant and were mostly significant for Scots pine $(p>0.05)$. The multiple regression analysis revealed that seedling height was also influenced by the interaction between mixture and experimental year. The model describing the height of Scots pine seedings with $R^{2}=0.92$ and standard error of estimation of 7.6 produced the best fit.

The addition of SS to CFA increased biomass yield relative to the pots containing $100 \%$ CFA. Biomass yield was highest in pots containing the highest percentage of SS (mixture No. 5). The biomass yield of control plants was $200 \%$ higher on average in comparison with the plants grown on CFA and SS mixtures. The greatest differences in biomass yield relative to control were noted in Norway spruce seedlings, and the smallest differences were noted in European alder seedlings (Figure 3).

\subsection{Salinity}

Salinity was highest in CFA without any additives. The addition of SS to CFA decreased electrical conductivity. Salinity decreased in all mixtures during the experiment, but differences were noted across pots containing different tree species. The greatest changes were observed in pots containing European alder and Scots pine seedlings. In these mixtures, salinity decreased significantly relative to the pots containing Norway spruce and European beech seedlings (Figure 4). 

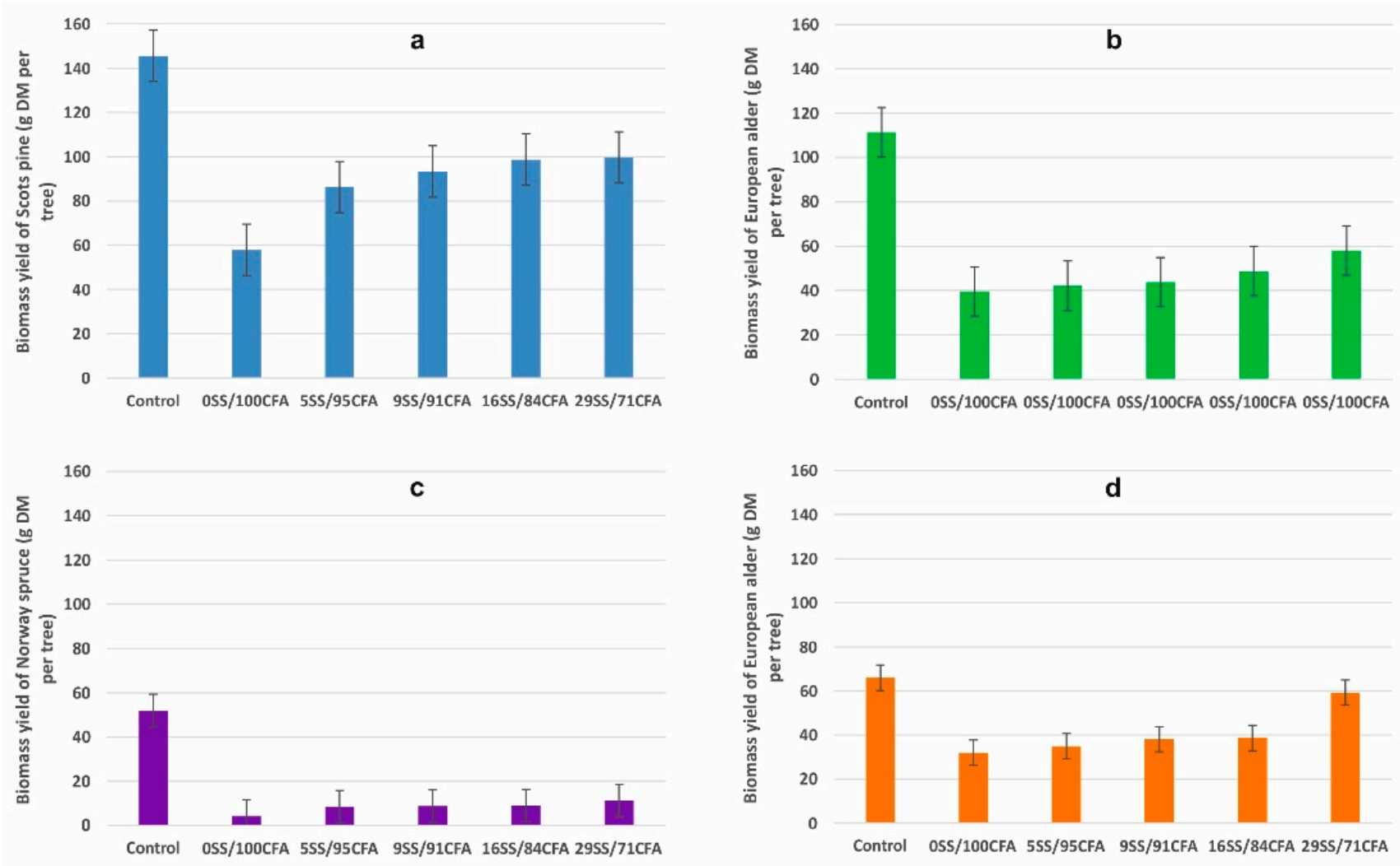

Figure 3. Biomass yield of Scots pine (a), European beech (b), Norway spruce (c) and European alder (d) seedlings. Data points represent the mean $\pm \mathrm{SD}, \mathrm{n}=4$.

\subsection{Chlorophyll a Fluorescence}

During the four-year study, the $\mathrm{Fv} / \mathrm{Fm}$ ratio of Scots pine was significantly differentiated in both spring and fall. The Fv/Fm ratio was lowest in the first two years of the study. In the first year, the $\mathrm{Fv} / \mathrm{Fm}$ ratio of all plants decreased significantly relative to control (on average by $20 \%$ ). It should be noted that the evaluated parameter was significantly correlated with the salt content of the evaluated mixtures. The $\mathrm{Fv} / \mathrm{Fm}$ ratio ranged from 0.75 to 0.79 in control pots, and from 0.57 (in 2014 and 2015) decrease of $26 \%$ to $0.71 \%$ (in 2016 and 2017) decrease of $7.8 \%$ in mixtures with the highest salt content (Figures 5a and 6a). Similar responses were noted in European beech seedlings, where the Fv/Fm ratio decreased with an increase in salinity in all experimental years. The $\mathrm{Fv} / \mathrm{Fm}$ ratio of control plants ranged from 0.83 (in 2017) to 0.79 (in 2014). Plants grown on mixtures with the highest salt content were characterized by a $\mathrm{Fv} / \mathrm{Fm}$ ratio of 0.57 (in 2014 and 2015) decrease of 30\% to $0.66 \%$ (in 2017) decrease of $18.5 \%$ (Figures $5 \mathrm{~b}$ and $6 \mathrm{~b}$ ). The $\mathrm{Fv} / \mathrm{Fm}$ ratio was highest in European alder which was most resistant to salt stress. The photosynthetic efficiency of European alder was lowest in the first year of the study, but the Fv/Fm ratio of this species continued to increase with a decrease in salinity in successive years (Figures $5 \mathrm{~d}$ and $6 \mathrm{~d}$ ). Norway spruce was least resistant to high salinity. This species was also characterized by the lowest photosynthetic efficiency during the four-year experiment (Figures $5 \mathrm{c}$ and $6 \mathrm{c}$ ). The $\mathrm{Fv} / \mathrm{Fm}$ ratio was significantly influenced by tree species, the salinity of CFA and sewage sludge mixtures and year. The Fv/Fm ratio was highest in European alder leaves (0.69) and lowest in Norway spruce needles (0.53). In deciduous species, the average values of the $\mathrm{Fv} / \mathrm{Fm}$ ratio decreased with an increase in mixture salinity and were $18 \%$ lower than in the control treatment at the highest salinity level. 

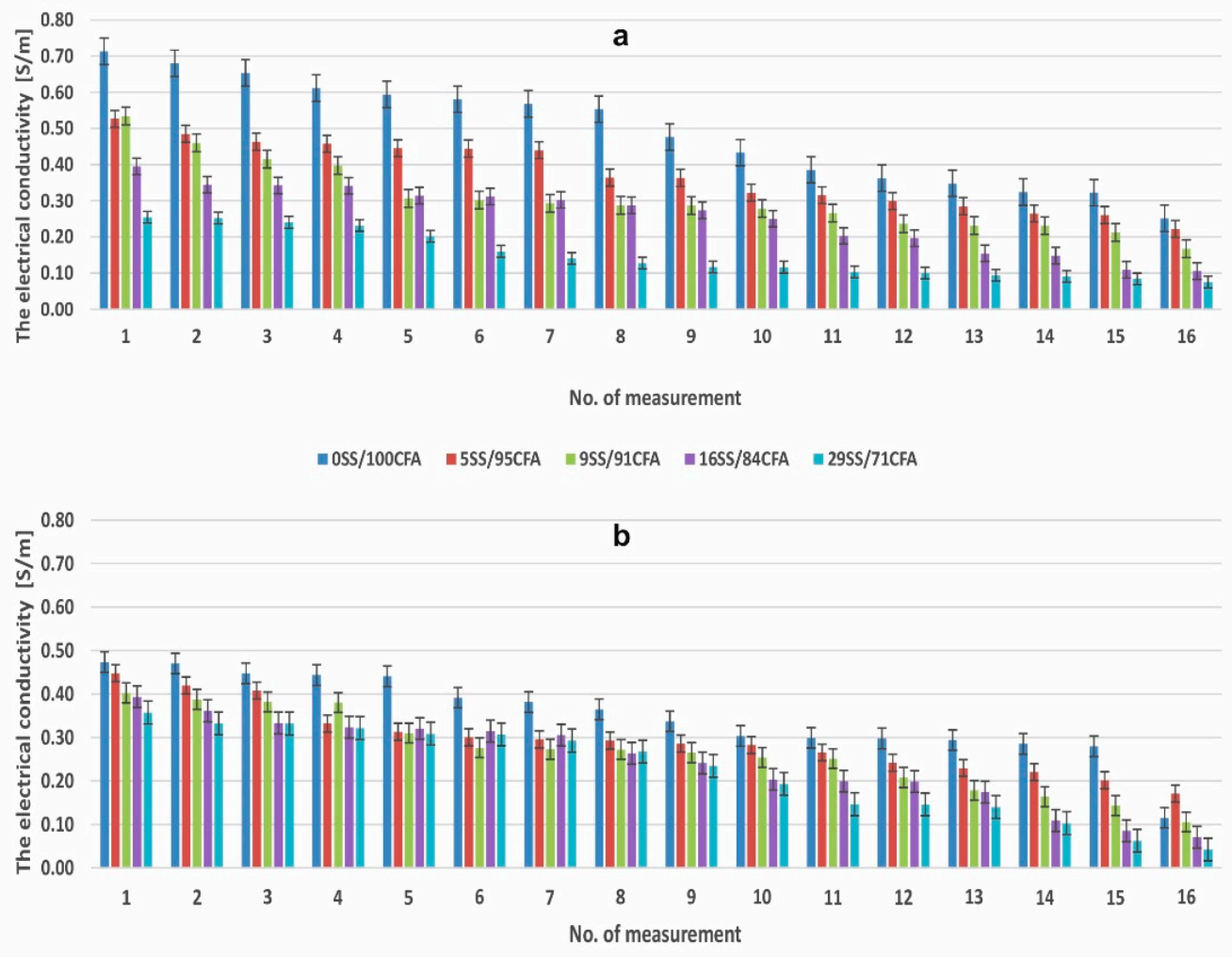

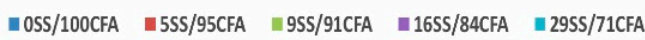

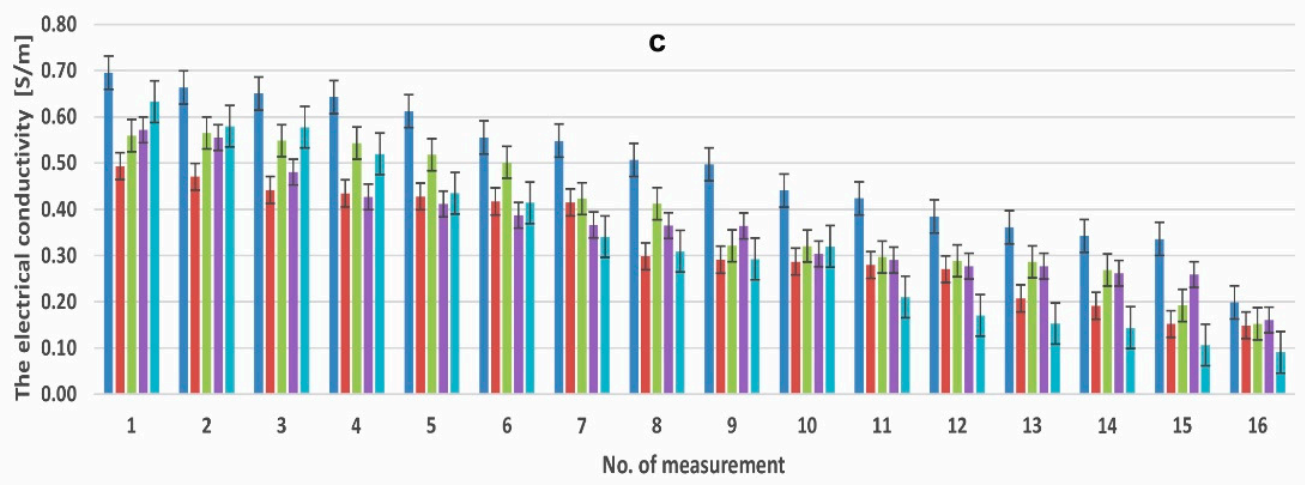

$\|$ OSS/100CFA $\amalg 5 S S / 95 C F A=9 S S / 91 C F A \backsim 16 S S / 84 C F A=29 S S / 71 C F A$

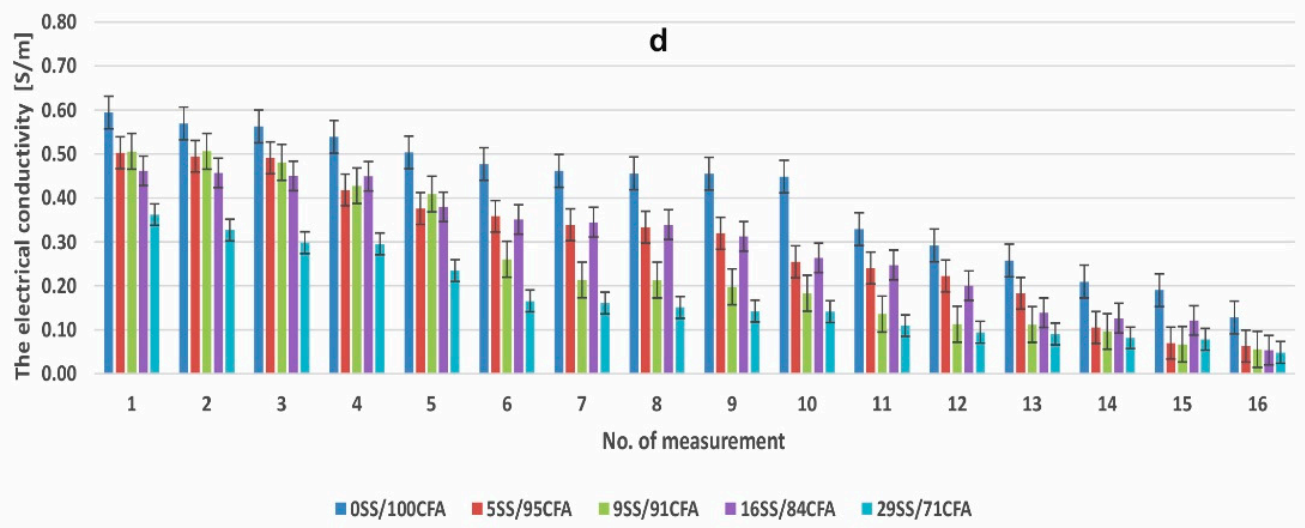

Figure 4. Electrical conductivity of mineral-based mixtures containing CFA and SS: (a) Scots pine; (b) European beech; (c) Norway spruce and (d) European alder. Data points represent the mean \pm SD, $n=4$. 

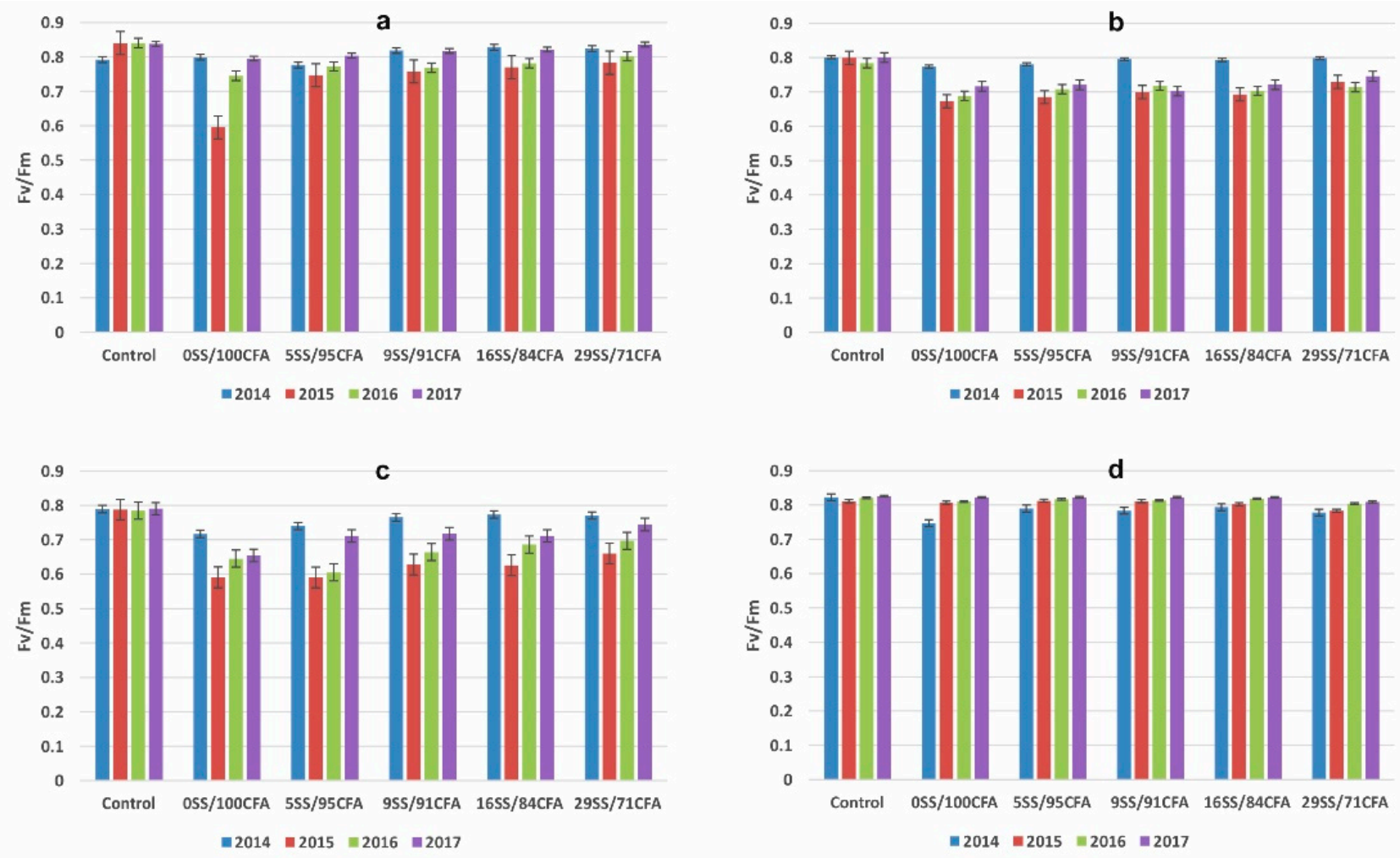

Figure 5. Chlorophyll a fluorescence measured in spring. Fv/Fm ratio of Scots pine (a), European beech (b), Norway spruce (c) and European alder (d). Data points represent the mean $\pm S D, n=4$.
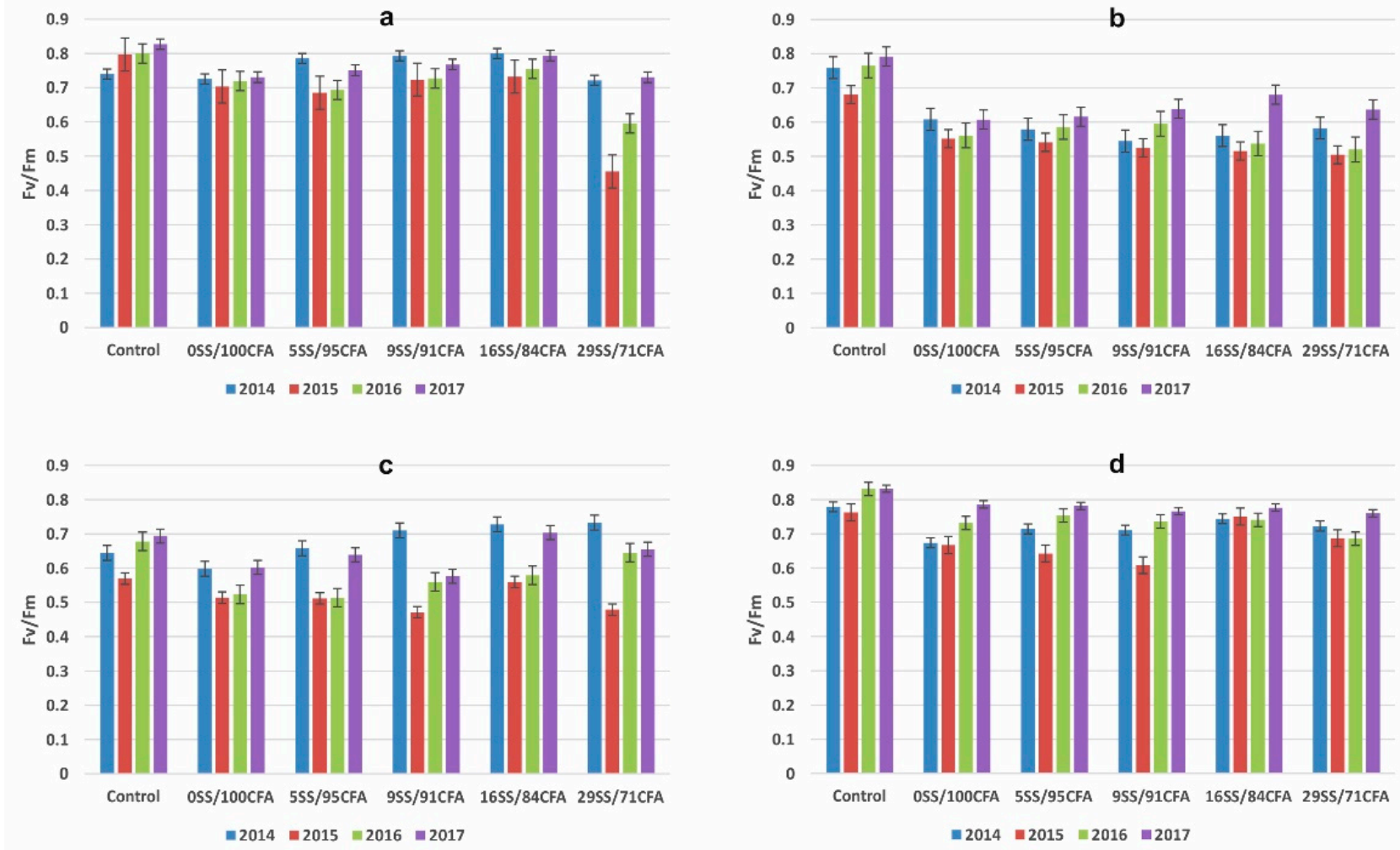

Figure 6. Chlorophyll a fluorescence measured in fall. Fv/Fm ratio of Scots pine (a), European beech (b), Norway spruce (c) and European alder (d). Data points represent the mean $\pm S D, n=4$. 


\section{Discussion}

Phytotoxicity tests are performed under laboratory conditions on samples of soil and plant material to determine the degree of ecotoxicological risk ex situ. The toxicity of fly ash and sewage sludge mixtures, measured based on the degree of root growth inhibition, increased with a rise in the percentage of fly ash relative to sewage sludge $[49,50]$. In the present experiment, an increase in the proportion of SS relative to CFA minimized the phytotoxicity of the analyzed mixtures. In the work of Selivanovskaya and Latypova [51], the addition of sewage sludge improved seed germination and the survival rate of seedlings. Oleszczuk [52,53] analyzed the phytotoxicity of mixed sewage sludge and observed that sludge composting improved both seed germination and root growth. Stefaniuk and Oleszczuk [54] investigated the toxic influence of sewage sludge on Lepidium sativum in the Phytotoxkit $\mathrm{F}$ test. The addition of biochar decreased the toxicity of substrate mixtures and enhanced root growth. Romanowska-Duda et al. [55] performed a phytotoxicity test to evaluate the fertilizing effect of ashes obtained from the combustion of sorghum and Jerusalem artichoke biomass. The tested ashes improved seed germination, enhanced plant growth and increased the biomass yield of Sorghum bicolor L. Samaras et al. [56] analyzed the phytotoxicity of SS and CFA on Sinapis alba, Sorghum saccharatum and Lepidium sativum grown in northwestern Greece and found that inhibition of root growth was minimized in mixtures with a high content of SS and a low content of CFA that were stabilized for a long period of time. Walter et al. [57] found that the stabilization of sewage sludge can decrease phytotoxicity by enabling seeds to adapt to adverse environmental conditions. Samaras et al. [56] demonstrated that ash and sewage sludge mixtures meet phytotoxicity and ecotoxicity standards when small amounts of fly ash are added to sewage sludge. However, in a study Jarosz-Krzemińska and Poluszyńska [58], biomass ash with desirable physicochemical properties added to soil exerted no toxic effects on seed germination or plant growth. In the current study, mixtures containing only CFA were most phytotoxic.

The biomass yield of trees is determined by their biometric parameters, such as height. The height of coniferous and deciduous seedlings continued to increase during the entire experiment. European alder and Scots pine were characterized by the greatest increase in height, which is consistent with the biology of these species [42]. Norway spruce and European beech grew at the slowest rate because their light requirements and growth rate increase with age [42]. Tree height was significantly correlated with the growing percentage of sewage sludge in substrate mixtures. In a study Antonkiewicz et al. [10], the biomass yield of grasses and legumes was higher on ash and sewage sludge mixtures than on mixtures containing ash or sewage sludge alone. A seven-year study conducted [59] in northwestern Spain demonstrated that sewage sludge fertilization enhanced the growth of Pinus radiata more effectively than mineral fertilization. Pinus radiata growing on substrates containing sewage sludge were around 35\% taller than the control trees. In the United States, treated sewage sludge has been widely used to fertilize forests for more than 50 years. Sewage sludge increases the availability of soil nutrients and contributes to a significant increase in seedling height [60]. Sewage sludge fertilization of mature pine stands in central Sweden increased nutrient concentrations in soil and fallen pine needles [61]. In a two-year experiment conducted in Russia, Pinus sylvestris trees grown on soil with an increased content of composted sewage sludge produced more biomass and were taller [51]. Similar observations were made in the present experiment, where the biometric parameters of plants were enhanced on mineral-based mixtures with a higher content of sewage sludge. According to Siebielec et al. [62], sewage sludge induces a similar or higher increase in biomass yield in comparison with mineral nitrogen. A decrease in the biomass yield of plants grown on ash mixtures has been attributed to the unfavorable physicochemical properties of ash [19]. Antonkiewicz et al. and Belay et al. [10,63] found that biomass combustion ashes induced a greater increase in biomass yield than CFA. Coal combustion ashes are deficient in nitrogen, which is why plant species that effectively fix this element have to be introduced in the first stage of biological reclamation. Alders are planted in pits, and CFA is added to soil. This is an effective method for managing coal ash and reclaiming 
polluted areas [64]. In a study Yu et al. [65], the application of smaller CFA doses (up to $25 \%$ of soil mass) increased biomass yield by around $30 \%$ relative to mixtures containing larger amounts of CFA (500\%-100\% of soil mass). Kenneth et al. [66] reported that CFA and SS mixtures containing up to $50 \%$ of ash inhibited plant growth and yields. Similar results were noted in the present study where tree growth was inhibited on mixtures with higher proportions of CFA. A study investigating various options for the reuse of sewage sludge and fly ash demonstrated that the physicochemical parameters of both wastes are complementary [67]. Sewage sludge was a source of nutrients, whereas fly ash improved the permeability of substrate mixtures. Ma et al. [67] also found that sewage sludge and fly ash mixtures containing $40 \%-60 \%$ of sewage sludge created the optimal conditions for plant growth and development. In a six-year study, Antonkiewicz et al. [10] found that plant yields increased with a rise in the content of municipal sewage sludge in ash and sludge mixtures. Similar observations were made in the current study where the growth of all tested plants was optimized on mineral-based mixtures containing $29 \%$ of sewage sludge.

Plant species with a high phytoextraction potential are used in reclamation programs to restore the macronutrient balance in soil $[68,69]$. The adaptive capacity of trees of the genus Alnus was described [9]. Alders are planted as a preceding crop to reduce soil pollution and increase soil nutrient levels before target species are introduced to the reclaimed area. The extent to which two alder species adapted to extremely unfavorable environmental conditions was analyzed [9] in a five-year experiment conducted in a fly ash landfill operated by the Bełchatów power plant. The study demonstrated that European alder grew at a faster rate than grey alder. In the present experiment, European alder was also the most rapidly growing tree species, which indicates that it is best suited for reclaiming strongly degraded areas. Coniferous trees were less resistant to adverse habitat conditions. In contrast, Bęś et al. [1] found that Scots pine adapted better to soils contaminated with diesel fuel than European beech.

Chlorophyll fluorescence is a reliable indicator of plant stress. This parameter is measured to determine the physiological status of plants before the first symptoms of leaf damage are observed. The $F v / F m$ ratio measures light utilization efficiency in primary photosynthetic reactions, and its value is proportional to the potential quantum efficiency of Photosystem II. The Fv/Fm ratio is regarded as a reliable indicator of the photochemical activity of the photosynthetic apparatus [70-74]. Fluorescence intensity varies depending on the duration and severity of environmental stress. In healthy leaves, the maximum potential quantum efficiency of PSII ( $F v / F m$ ) ranges from 0.76 to 0.85 . The $F v / F m$ ratio decreases in response to stressors. Values in the range of $0.2-0.3$ are indicative of irreversible changes in the structure of PSII [71,75-77]. For this reason, rapid fluorescence measurements provide valuable information about the specific photosynthetic responses of different tree species to environmental factors [78]. According to Romanowska-Duda et al. [79], the maximum potential quantum efficiency of PSII can be used to monitor parameters that are dependent on chlorophyll content and activity. Therefore, this indicator can be applied to measure plant growth, gas exchange, the activity of selected enzymes, biomass yield and nutrient concentrations.

In the present study, the photochemical activity of the photosynthetic apparatus ( $F v / F m$ ratio) was lower in fall than in spring in all years. In the first year of the experiment, the $\mathrm{Fv} / \mathrm{Fm}$ ratio was low in all plant species, and all evaluated mixtures were characterized by the highest salinity, which decreased $F v / F m$ values. This trend was maintained in the second year. A gradual increase in the $\mathrm{Fv} / \mathrm{Fm}$ ratio was noted in the third year, and it was correlated with the progressing decline in salinity levels. The strongest stress response to the high salt content of mixtures was observed in the first year, and Scots pine and European alder adapted most rapidly to high salinity. These species were characterized by the most rapid growth and high values of the $F v / F m$ ratio ( 0.75 on average). High salinity exerted the most adverse effect on Norway spruce needles whose $\mathrm{Fv} / \mathrm{Fm}$ ratio remained below 0.6 throughout the experiment regardless of the composition of substrate mixtures. 
The inhibitory influence of salt on the viability of needles and the photosynthetic efficiency of Norway spruce was also reported [80]. European beech leaves were characterized by somewhat higher values of $F v / F m$, in particular in the fourth year of the experiment. In the current study, the $\mathrm{Fv} / \mathrm{Fm}$ ratio was highest ( 0.8 on average) in Scots pines grown on mixture No. 5 (with the highest proportions of sewage sludge), which is indicative of good tree health. In a field experiment conducted by Salmela et al. [81], the photochemical efficiency ( $F v / F m$ ratio) of healthy pine needles was determined at 0.7 under field conditions. The $\mathrm{Fv} / \mathrm{Fm}$ ratio of Scots pine needles is modified under drought conditions. Pearson et al. [82] evaluated the tolerance of peat-grown two-year Scots pine seedlings to waterlogging and drought. Under controlled conditions, drought visibly inhibited root and shoot growth and decreased photochemical efficiency $(\mathrm{Fv} / \mathrm{Fm})$, whereas water stress had a minor influence on the health status of Scots pines. In the present study, photochemical efficiency was lowest in plants grown on CFA without the addition of SS. In the work Gajić et al. [83], the Fv/Fm ratio was also low in Dactylis glomerata L. growing on fly ash. Low values of the Fv/Fm ratio in the range of 0.429 to 0.691 were also reported in herbaceous plants, shrubs and trees, including Cirsium arvense, Epilobium collinum, Crepis bienis, Eupatorium cannabinum, Verbascum phlomoides, Calamagrostis epigejos, Oenothera biennis and Festuca rubra, growing on fly ash [84-87]. According to Żołnierz et al. [88], fly ash creates unfavorable conditions for plant growth on account of its alkalinity, high salt content and binding capacity. However, mixtures combining CFA with SS or boulder clay have a porous structure in the surface layer, which facilitates root penetration and promotes plant growth. In the current experiment, Scots pines and European alders grown on mineral-based mixtures containing CFA and SS were also in better health than the remaining tree species. They were also characterized by high values of the $\mathrm{Fv} / \mathrm{Fm}$ ratio, which indicates that they were most resistant to salinity. The mixture with the highest content of sewage sludge created optimal conditions for plant growth and development, as evidenced by the highest $\mathrm{Fv} / \mathrm{Fm}$ ratio. Plants grown on the above mixture were also characterized by the most rapid growth. Burducea et al. [89] analyzed basil plants grown on substrates fertilized with sewage sludge. Sludge containing essential metal ions and high concentrations of plant-available nitrogen and phosphorus increased the content of assimilatory pigments in basil leaves. According to Burducea et al. and Pengcheng et al. [89,90], these nutrients are essential for chlorophyll synthesis. In the present study, plants grown on the mixture with the highest content of sewage sludge were characterized by the highest assimilatory activity, as demonstrated by high values of the Fv/Fm ratio. Mazen et al. and Zhang et al. [91,92] reported positive correlations between nitrogen and chlorophyll concentrations in the leaves of wheat, maize and jute mallow. According to Martinez et al. [93], these observations can be attributed to the fact that chlorophyll molecules contain nitrogen. Herrmann et al., Homolová et al. and Camino et al. [94-96] demonstrated that chlorophyll is the most widely used indicator of nitrogen content. Camino et al., Corp et al., Schächtl et al. and Cendrero-Mateo et al. [96-99] reported a strong correlation between fluorescence emission and nitrogen fertilization. Sewage sludge is abundant in nitrogen, which is why assimilatory activity was highest in seedlings grown on mixture No. 5. Sewage sludge also contains phosphorus, and according to School and Shamshiri [100], an increase in the concentration of plant-available phosphorus increased the $\mathrm{Fv} / \mathrm{Fm}$ ratio of pistachio seedlings by improving their nutritional status. The biological significance of phosphorus was also discussed [101]. Kalaji et al. [102] analyzed the responses of maize and tomato plants to nutrient deprivation and found that nutrient deficiencies compromised photochemical reactions in photosynthesis. The cited authors noted that chlorophyll fluorescence data can support early detection of nutrient deficiencies in some plant species. In the present study, plants grown on substrates with the highest proportions of sewage sludge were characterized by high $\mathrm{Fv} / \mathrm{Fm}$ values; therefore, they were adequately supplied with nutrients. According to RomanowskaDuda et al. [79], the maximum potential quantum efficiency of PSII in sorghum can be an effective and non-destructive marker of plant vigor that supports rapid evaluations of plant responses to waste from corn biomass biodigestion to methane. In the current 
experiment, plants grown on mineral-based mixtures containing CFA and sewage sludge differed in the values of the Fv/Fm ratio. Tan et al. [103] also found that physiological plant responses determined based on measurements of chlorophyll fluorescence can be species-specific. According to Romanowska-Duda et al. [79], measurements of the maximum potential quantum efficiency of PSII are useful in evaluations of the physiological activity of plants and can be recommended as markers of plant development. Similar observations were made by Badek et al. [104,105] in a study of tomatoes and China asters and by Romanowska-Duda et al. [106] who reported on the stimulatory effect of sewage sludge on the biomass yield of energy crops.

In the present study, plants grown on substrates with the highest proportions of CFA were most phytotoxic. However, CFA did not completely inhibit the growth of Scots pine, European alder and European beech. Seedlings grown on mixtures No. 2, 3 and 4 grew at a slower rate and were characterized by low values of the $\mathrm{Fv} / \mathrm{Fm}$ ratio.

Scots pine, Norway spruce, European beech and European alder are the main forest tree species that cover around $80 \%$ of total forest area in Poland. Scots pine and European alder have been extensively described in the literature, and they are widely used to reclaim degraded areas. They are characterized by rapid growth, and they easily adapt to a broad range of environmental conditions. In turn, Norway spruce and European beech are more frequently used as target species in the biological reclamation of degraded soils with high trophic requirements. These species were selected for the study to determine their suitability for reclamation programs. The current experiment was conducted on mineralbased mixtures with the addition of CFA and SS. New fertilizer regulations promote the application of organic fertilizers, biowaste and recycled fertilizers, such as fly ash and sewage sludge. This study was undertaken with the above in mind to propose alternative solutions to biowaste storage. The present findings indicate that fly ash and sewage sludge can be effectively used as soil amendments and forest fertilizers to complete the biogeochemical cycle. Further research is needed to determine the applicability of various ash-sludge mixtures, including fly ash from biomass combustion, for land reclamation.

\section{Conclusions}

Mineral-based mixtures containing a combination of CFA and SS had a more beneficial influence on seedling growth than mixtures containing only one type of the analyzed waste products. Mixtures enhanced with both CFA and SS affected the development of the evaluated tree species. The mixtures had high salt content, which inhibited seedling growth and compromised their health in the first two years of the experiment. Salinity levels decreased in the following two years of the study, which improved the growth of Scots pine and European alder. Norway spruce and European beech were least resistant to salt stress. At the end of the four-year experiment, the greatest increment in tree height and biomass yield was noted in European alder and Scots pine. These species were also characterized by the highest photosynthetic efficiency and high values of the Fv/Fm ratio. European alder and Scots pine can be recommended for land reclamation in areas where mineral-based mixtures enhanced with CFA and SS constitute the surface layer of soil substrates. Mixtures containing 29\% of SS created the optimal conditions for the growth of all analyzed tree species.

Author Contributions: Conceptualization, A.B.; methodology, A.B.; software, Ł.S.; validation, A.B.; formal analysis, A.B.; investigation, A.B.; resources, A.B. and Ł.S.; data curation, K.S.; writingoriginal draft preparation, A.B. and Ł.S.; writing-review and editing, A.B. and Ł.S.; visualization, K.S. and Ł.S.; supervision, A.B. and Ł.S.; project administration, A.B.; funding acquisition, A.B. All authors have read and agreed to the published version of the manuscript.

Funding: Project financially co-supported by Minister of Science and Higher Education in the range of the program entitled "Regional Initiative of Excellence" for the years 2019-2022, Project No. 010/RID/2018/19, amount of funding 12.000.000 PLN". The results presented in this paper were obtained as part of a comprehensive study financed by the University of Warmia and Mazury in Olsztyn, Faculty of Agriculture and Forestry, Department of Chemistry (grant No. 30.610.002-110). 
Institutional Review Board Statement: Not applicable.

Informed Consent Statement: Not applicable.

Data Availability Statement: Not applicable.

Acknowledgments: The authors would like to thank the staff of the Department for technical support during the experiment.

Conflicts of Interest: The authors declare no conflict of interest.

\section{References}

1. Bęś, A.; Warmiński, K.; Adomas, B. Long-term responses of Scots pine (Pinus sylvestris L.) and European beech (Fagus sylvatica L.) to the contamination of light soils with diesel oil. Environ. Sci. Pollut. Res. 2019, 26, 10587-10608. [CrossRef]

2. Antonkiewicz, J.; Kołodziej, B.; Bielińska, E.J.; Gleń-Karolczyk, K. The use of macroelements from municipal sewage sludge by the Multiflora rose and the Virginia fanpetals. J. Ecol. Eng. 2018, 19, 1-13. [CrossRef]

3. Liu, Y.; Su, S.; Zhang, L.; Liu, Y.; Huang, Z.; He, D.; Kong, D. Effect of exogenous calcium on lotus adaptation to salt stress. Hortic. Sci. 2020, 32, 243-252.

4. Statistical Yearbook of Forestry 2019; Statistics Poland: Warszawa, Poland, 2019; p. 39.

5. Ram, L.C.; Masto, R.E. Fly ash for soil amelioration: A review on the influence of ash blending with inorganic and organic amendments. Earth Sci. Rev. 2014, 128, 52-74. [CrossRef]

6. Wyszkowski, M.; Radziemska, M. The effect of chromium content in soil on the concentration of some mineral elements in plants. Fresenius Environ. Bull. 2009, 18, 1039-1045.

7. Radziemska, M.; Mazur, Z.; Jeznach, J. Influence of applying halloysite and zeolite to soil contaminated with nickel on the content of selected elements in Maize (Zea mays L.). Chem. Eng. Trans. 2013, 32, 301-306.

8. Mashau, A.; Gitari, W.; Akinyemi, S.A. Evaluation of the bioavailability and translocation of selected heavy metals by Brassica juncea and Spinacea oleracea L. for a South African power utility coal fly ash. Int. J. Environ. Res. Public Health 2018, $15,2841$. [CrossRef] [PubMed]

9. Krzaklewski, W.; Pietrzykowski, M.; Woś, B. Survival and growth of alders (Alnus glutinosa (L.) Gaertn. and Alnus incana (L.) Moench) on fly ash technosols at different substrate improvement. Ecol. Eng. 2012, 49, 35-40. [CrossRef]

10. Antonkiewicz, J.; Popławska, A.; Kołodziej, B.; Ciarkowska, K.; Gambus, F.; Bryk, M.; Babula, J. Application of ash and municipal sewage sludge as macronutrient sources in sustainable plant biomass production. J. Environ. Manag. 2020, 264, 110450. [CrossRef]

11. Haynes, R.J. Reclamation and revegetation of fly ash disposal sites-Challenges and research needs. J. Environ. Manag. 2009, 90, 43-53. [CrossRef] [PubMed]

12. Mandal, S.; Kunhikrishnan, A.; Bolan, N.; Wijesekara, H.; Naidu, R. Application of biochar produced from biowaste materials for environmental protection and sustainable agriculture production. Environ. Mater. Waste Resour. Recovery Pollut. Prev. 2016, 73-89. [CrossRef]

13. Zhen, G.; Lu, X.; Kato, H.; Zhao, Y.; Li, Y.-Y. Overview of pretreatment strategies for enhancing sewage sludge disintegration and subsequent anaerobic digestion: Current advances, full-scale application and future perspectives. Renew. Sustain. Energy Rev. 2017, 69, 559-577. [CrossRef]

14. Cieślik, B.M.; Namieśnik, J.; Konieczka, P. Review of sewage sludge management: Standards, regulations and analytical methods. J. Clean. Prod. 2015, 90,1-15. [CrossRef]

15. European Union Directive 2009/28/EC of the European Parliament and of the Council of 23 April 2009 on the promotion of the Use of Energy from Renewable Sources and Amending and Subsequently Repealing Directives 2001/77/EC and 2003/30/EC (Text with EEA Relevance). Off. J. Eur. Union. 2009, 5, 39-85.

16. Šuňovská, A.; Horník, M.; Piṕǐ̌ka, M.; Lesný, J.; Augustín, J.; Hostin, S. Characterization of soil additive derived from sewage sludge. Nova Biotechnol. Chim. 2013, 12, 141-153. [CrossRef]

17. Wierzbowska, J.; Sienkiewicz, S.; Krzebietke, S.; Sternik, P. Sewage sludge as a source of nitrogen and phosphorus for Virginia fanpetals. Bulg. J. Agric. Sci. 2016, 22, 722-727.

18. Gong, B.; Deng, Y.; Yang, Y.; Tan, S.N.; Liu, Q.; Yang, W. Solidification and biotoxicity assessment of thermally treated municipal solid waste incineration (MSWI) fly ash. Int. J. Environ. Res. Public Health 2017, 14, 626. [CrossRef]

19. Schumann, A.W.; Sumner, M. Formulation of environmentally sound waste mixtures for land application. Water Air Soil Pollut. 2004, 152, 195-217. [CrossRef]

20. Quant, B. Przeciwdziałanie negatywnemu oddziaływaniu składowisk odpadów paleniskowych na otoczenie z wykorzystaniem osadów ściekowych. Ekol. Tech. 2000, 8, 95-99. (In Polish)

21. Rutkowska, B.; Szulc, W.; Łabętowicz, J. Ocena zagrożeń dla środowiska glebowego w warunkach wnoszenia metali ciężkich w komunalnym osadzie ściekowym. Rocz. Glebozn. 2004, 55, 203-208. (In Polish)

22. Greinert, A.; Mrówczyńska, M.; Szefner, W. Study on the possibilities of natural use of ash granulate obtained from the combustion of pellets from plant biomass. Energies 2019, 12, 2569. [CrossRef]

23. Kicińska, A.; Kosa-Burda, B.; Kozub, P. Utilization of a sewage sludge for rehabilitating the soils degraded by the metallurgical industry and a possible environmental risk involved. Hum. Ecol. Risk Assess. 2018, 24, 1990-2010. [CrossRef] 
24. Ukwattage, N.L.; Ranjith, P.G.; Bouazza, M. The use of coal combustion fly ash as a soil amendment in agricultural lands (with comments on its potential to improve food security and sequester carbon). Fuel 2013, 109, 400-408. [CrossRef]

25. Pietrzykowski, M.; Krzaklewski, W.; Woś, B. Zawartość pierwiastków śladowych (Mn, Zn, Cu, Cd, Pb, Cr) w liściach olsz (Alnus sp.) Zastosowanych jako gatunki fitomelioracyjne na składowisku odpadów paleniskowych. Zeszyty Naukowe. Inżynieria Środowiska Uniwersytet Zielonogórski 2013, 151, 26-34. (In Polish)

26. Leewis, M.C.; Reynolds, C.M.; Leigh, M.B. Long-term effects of nutrient addition and phytoremediation on diesel and crude oil contaminated soils in subarctic Alaska. Cold Reg. Sci. Technol. 2013, 96, 129-137. [CrossRef]

27. Yuan, Y.; Zhao, Z.; Bai, Z.; Wang, H.; Wang, Y.; Niu, S. Reclamation patterns vary carbon sequestration by trees and soils in an opencast coal mine. Catena 2016, 147, 404-410. [CrossRef]

28. Schaberg, P.G.; DeHayes, D.H.; Hawley, G.J.; Nijensohn, S.E. Anthropogenic alterations of genetic diversity within tree populations: Implications for forest ecosystem resilience. For. Ecol. Manag. 2008, 256, 855-862. [CrossRef]

29. Bandyopadhyay, S.; Novo, L.A.B.; Pietrzykowski, M.; Maiti, S.K. Assessment of forest ecosystem development in coal mine degraded land by using integrated mine soil quality index (IMSQI): The evidence from India. Forests 2020, 11, 1310. [CrossRef]

30. Mukhopadhyay, S.; Maiti, S.K.; Masto, R.E. Use of reclaimed mine soil index (RMSI) for screening of tree species for reclamation of coal mine degraded land. Ecol. Eng. 2013, 57, 133-142. [CrossRef]

31. Muilu-Mäkelä, R.; Vuosku, J.; Läärä, E.; Saarinen, M.; Heiskanen, J.; Häggman, H.; Sarjala, T. Water availability influences morphology, mycorrhizal associations, PSII efficiency and polyamine metabolism at early growth phase of Scots pine seedlings. Plant. Physiol. Biochem. 2015, 88, 70-81. [CrossRef]

32. Löf, M.; Bolte, A.; Welander, N.T. Interacting effects of irradiance and water stress on dry weight and biomass partitioning in Fagus sylvatica seedlings. Scand. J. For. Res. 2005, 20, 322-328. [CrossRef]

33. Chakraborty, T.; Saha, S.; Matzarakis, A.; Reif, A. Influence of multiple biotic and abiotic factors on the crown die-back of European beech trees at their drought limit. Flora 2017, 229, 58-70. [CrossRef]

34. Gazol, A.; Camarero, J.J.; Jiménez, J.J.; Moret-Fernández, D.; López, M.V.; Sangüesa-Barreda, G.; Igual, J.M. Beneath the canopy: Linking drought-induced forest die off and changes in soil properties. For. Ecol. Manag. 2018, 422, 294-302. [CrossRef]

35. Derome, J.; Saarsalmi, A. The effect of liming and correction fertilisation on heavy metal and macronutrient concentrations in soil solution in heavy-metal polluted Scots pine stands. Environ. Pollut. 1999, 104, 249-259. [CrossRef]

36. Grobelak, A.; Placek, A.; Grosser, A.; Singh, B.R.; Almås, Å.R.; Napora, A.; Kacprzak, M. Effects of single sewage sludge application on soil phytoremediation. J. Clean. Prod. 2017, 155, 189-197. [CrossRef]

37. Pajak, M.; Halecki, W.; Gasiorek, M. Accumulative response of Scots pine (Pinus sylvestris L.) and silver birch (Betula pendula Roth) to heavy metals enhanced by $\mathrm{Pb}-\mathrm{Zn}$ ore mining and processing plants: Explicitly spatial considerations of ordinary kriging based on a GIS approach. Chemosphere 2017, 168, 851-859. [CrossRef] [PubMed]

38. Stefanowicz, A.M.; Stanek, M.; Woch, M.W. High concentrations of heavy metals in beech forest understory plants growing on waste heaps left by $\mathrm{Zn}-\mathrm{Pb}$ ore mining. J. Geochem. Explor. 2016, 169, 157-162. [CrossRef]

39. Gruba, P. The influence of trees on spatial variability of $\mathrm{pH}$ in top horizons of forest soil. Sylwan 2009, 153, 332-337.

40. Horodecki, P.; Jagodziński, A.M. Tree species effects on litter decomposition in pure stands on afforested post-mining sites. For. Ecol. Manag. 2017, 406, 1-11. [CrossRef]

41. Krzaklewski, W. Podstawy Rekultywacji Leśnej; Wydawnictwo Uniwersytetu Rolniczego w Krakowie: Kraków, Poland, 2017; pp. 111-125. (In Polish)

42. Jaworski, A. Charakterystyka Hodowlana Drzew i Krzewów Leśnych; Powszechne Wydawnictwo Rolnicze i Leśne: Warszawa, Poland, 2011; pp. 37-365. (In Polish)

43. Pietrzykowski, M.; Woś, B.; Pająk, M.; Wanic, T.; Krzaklewski, W.; Chodak, M. The impact of alders (Alnus spp.) on the physico-chemical properties of technosols on a lignite combustion waste disposal site. Ecol. Eng. 2018, 120, 180-186. [CrossRef]

44. Eckenwalder, J.E. Conifers of the World: The Complete Reference; Timber Press: Portland, OR, USA, 2009; pp. 90-111.

45. Chodak, M. Near-infrared spectroscopy for rapid estimation of microbial properties in reclaimed mine soils. J. Plant. Nutr. Soil Sci. 2011, 174, 702-709. [CrossRef]

46. Knoche, D.; Ertele, C. Infection of Scots pine afforestation (Pinus sylvestris L.) by annosum root rot (Heterobasidion annosum (Fr.) Bref.) in the eastern german lignite district. Civ. Environ. Eng. Rep. 2010, 4, 35-45.

47. Pietrzykowski, M. (Red.) Analiza i Optymalizacja Metod Klasyfikacji Siedlisk i Kryteriów oceny Rekultywacji leśnej na Wybranych Terenach Pogórniczych w Polsce; Wydawnictwo Uniwersytetu Rolniczego: Kraków, Poland, 2010; Volume 1, p. 214. (In Polish)

48. Mauer, O.; Mauerová, P. The effect of planting stock growing technology on the development of mycorrhiza. Sylwan 2009, 153, 117-124.

49. Di Carlo, E.; Boullemant, A.; Courtney, R. Ecotoxicological risk assessment of revegetated bauxite residue: Implications for future rehabilitation programmes. Sci. Total Environ. 2020, 698, 134344. [CrossRef]

50. Papadimitriou, C.A.; Haritou, I.; Samaras, P.; Zouboulis, A.I. Evaluation of leaching and ecotoxicological properties of sewage sludge-fly ash mixtures. Environ. Res. 2008, 106, 340-348. [CrossRef] [PubMed]

51. Selivanovskaya, S.Y.; Latypova, V.Z. Effects of composted sewage sludge on microbial biomass, activity and pine. J. Waste Manag. 2006, 26, 1253-1258. [CrossRef] [PubMed]

52. Oleszczuk, P. The toxicity of composts from sewage sludges evaluated by the direct contact tests phytotoxkit and ostracodtoxkit. J. Waste Manag. 2008, 28, 1645-1653. [CrossRef] [PubMed] 
53. Oleszczuk, P. Phytotoxicity of municipal sewage sludge composts related to physico-chemical properties, PAHs and heavy metals. Ecotoxicol. Environ. Saf. 2008, 69, 496-505. [CrossRef]

54. Stefaniuk, M.; Oleszczuk, P. Addition of biochar to sewage sludge decreases freely dissolved PAHs content and toxicity of sewage sludge-amended soil. Environ. Pollut. 2016, 218, 242-251. [CrossRef]

55. Romanowska-Duda, Z.; Janas, R.; Grzesik, M. Application of Phytotoxkit in the quick assessment of ashes suitability as fertilizers in sorghum crops. Int. Agrophys. 2019, 33, 145-152. [CrossRef]

56. Samaras, P.; Papadimitriou, C.A.; Haritou, I.; Zouboulis, A.I. Investigation of sewage sludge stabilization potential by the addition of fly ash and lime. J. Hazard. Mater. 2008, 154, 1052-1059. [CrossRef]

57. Walter, I.; Martinez, F.; Cala, V. Heavy metal speciation and phytotoxic effects of three representative sewage sludges for agricultural uses. Environ. Pollut. 2006, 139, 507-514. [CrossRef]

58. Jarosz-Krzemińska, E.; Poluszyńska, J. Repurposing fly ash derived from biomass combustion in fluidized bed boilers in large energy power plants as a mineral soil amendment. Energies 2020, 13, 4805. [CrossRef]

59. Mosquera-Losada, M.R.; Fernández-Núñez, E.; Rigueiro-Rodríguez, A. Pasture, tree and soil evolution in silvopastoral systems of Atlantic Europe. For. Ecol. Manag. 2006, 232, 135-145. [CrossRef]

60. Nichols, C.G. US forestry uses of municipal sewage sludge. In Alternative Uses for Sewage Sludge Proceedings of a Conference Organised by WRc Medmenham and Held at the University of York, UK on 5-7 September 1989; Pergamon: York, UK, 1991 ; pp. 155-165.

61. Bramryd, T. Effects of liquid and dewatered sewage sludge applied to a Scots pine stand (Pinus sylvestris L.) in Central Sweden. For. Ecol. Manag. 2001, 147, 197-216. [CrossRef]

62. Siebielec, G.; Siebielec, S.; Lipski, D. Long-term impact of sewage sludge, digestate and mineral fertilizers on plant yield and soil biological activity. J. Clean. Prod. 2018, 187, 372-379. [CrossRef]

63. Belay, A.; Claassens, A.; Wehner, F. Effect of direct nitrogen and potassium and residual phosphorus fertilizers on soil chemical properties, microbial components and maize yield under long-term crop rotation. Biol. Fertil. Soils. 2002, 35, 420-427.

64. Pietrzykowski, M.; Woś, B.; Pają, M.; Wanic, T.; Krzaklewski, W.; Chodak, M. Reclamation of a lignite combustion waste disposal site with alders (Alnus sp.): Assessment of tree growth and nutrient status within 10 years of the experiment. Environ. Sci. Pollut. Res. 2018, 25, 17091-17099. [CrossRef] [PubMed]

65. Yu, C.-L.; Deng, Q.; Jian, S.; Li, J.; Dzantor, E.K.; Hui, D. Effects of fly ash application on plant biomass and element accumulations: A meta-analysis. Environ. Pollut. 2019, 250, 137-142. [CrossRef]

66. Kenneth, S.; Sajwan, W.; Ornes, H.; Youngblood, T. The effect of fly ash/sewage sludge mixtures and application rates on biomass production. J. Environ. Sci. Health A 1995, 30, 1327-1337.

67. Ma, B.; Liu, L.; Zhao, Y.; Zhang, C.; Hu, Z.; Leng, P. Evaluation of the environmental and plant growth effectiveness of a new substrate consisting of municipal sludge and fly ash. J. Waste Manag. 2019, 99, 163-171. [CrossRef]

68. Kirchmann, H.; Börjesson, G.; Kätterer, T.; Cohen, Y. From agricultural use of sewage sludge to nutrient extraction: A soil science outlook. Ambio 2016, 46, 143-154. [CrossRef] [PubMed]

69. Radziemska, M.; Bęś, A.; Gusiatin, Z.M.; Cerda, A.; Mazur, Z.; Jeznach, J.; Kowal, P.; Brtnický, M. The combined effect of phytostabilization and different amendments on remediation of soils from post-military areas. Sci. Total Environ. 2019, 688, 37-45. [CrossRef]

70. Dabrowski, P.; Baczewska, A.H.; Pawluśkiewicz, B.; Paunov, M.; Alexantrov, V.; Goltsev, V.; Kalaji, M.H. Prompt chlorophyll a fluorescence as a rapid tool for diagnostic changes in PSII structure inhibited by salt stress in Perennial ryegrass. J. Photochem. Photobiol. B Biol. 2016, 157, 22-31. [CrossRef] [PubMed]

71. Kalaji, H.M.; Račková, L.; Paganová, V.; Swoczyna, T.; Rusinowski, S.; Sitko, K. Can chlorophyll- a fluorescence parameters be used as bio-indicators to distinguish between drought and salinity stress in Tilia cordata Mill. Environ. Exp. Bot. 2018, 152, 149-157. [CrossRef]

72. Baker, N.R.; Oxborough, K.; Lawson, T.; Morison, J.I.L. High resolution imaging of photosynthetic activities of tissues, cells and chloroplasts in leaves. J. Exp. Bot. 2001, 52, 615-621. [CrossRef] [PubMed]

73. Lawson, T.; Oxborough, K.; Morison, J.I.L.; Baker, N.R. Responses of photosynthetic electron transport in stomatal guard cells and mesophyll cells in intact leaves to light, $\mathrm{CO}_{2}$, and humidity. Plant. Physiol. 2002, 128, 52-62. [CrossRef]

74. Sikorski, Ł.; Baciak, M.; Bęś, A.; Adomas, B. The effects of glyphosate-based herbicide formulations on Lemna minor, a non-target species. Aquat. Toxicol. 2019, 209, 70-80. [CrossRef]

75. Banks, J.M. Chlorophyll fluorescence as a tool to identify drought stress in Acer genotypes. Environ. Exp. Bot. 2018, 155, 118-127. [CrossRef]

76. Percival, G.C.; Keary, I.P.; AL-Habsi, S. An assessment of the drought tolerance of Fraxinus genotypes for urban landscape plantings. Urban. For. Urban. Green. 2006, 5, 17-27. [CrossRef]

77. Sakugawa, H.; Cape, J.N. Harmful effects of atmospheric nitrous acid on the physiological status of Scots pine trees. Environ. Pollut. 2007, 147, 532-534. [CrossRef]

78. Pšidová, E.; Živčák, M.; Stojnić, S.; Orlović, S.; Gömöry, D.; Kučerová, J.; Ditmarová, L'.; Střelcová, K.; Brestič, M.; Kalaji, H.M. Altitude of origin influences the responses of PSII photochemistry to heat waves in European beech (Fagus sylvatica L.). Environ. Exp. Bot. 2018, 152, 97-106. [CrossRef]

79. Romanowska-Duda, Z.; Grzesik, M.; Jansa, R. Maximal efficiency of PSII as a marker of sorghum development fertilized with waste from a biomass biodigestion to methane. Front. Plant. Sci. 2019, 9, 1920. [CrossRef] 
80. Kayama, M.; Quoreshi, A.M.; Kitaoka, S.; Kitahashi, Y.; Sakamoto, Y.; Maruyama, Y.; Kitao, M.; Koike, T. Effects of deicing salt on the vitality and health of two spruce species, Picea abies Karst., and Picea glehnii Masters planted along roadsides in Northern Japan. Environ. Pollut. 2003, 124, 127-137. [CrossRef]

81. Salmela, M.J.; Cavers, S.; Cottrell, J.E.; Iason, G.R.; Ennos, R.A. Seasonal patterns of photochemical capacity and spring phenology reveal genetic differentiation among native Scots pine (Pinus sylvestris L.) populations in Scotland. For. Ecol. Manag. 2011, 262, 1020-1029. [CrossRef]

82. Pearson, M.; Saarinen, M.; Nummelin, L.; Heiskanen, J.; Roitto, M.; Sarjala, T.; Laine, J. Tolerance of peat-grown Scots pine seedlings to waterlogging and drought: Morphological, physiological, and metabolic responses to stress. For. Ecol. Manag. 2013, 307, 43-53. [CrossRef]

83. Gajić, G.; Djurdjević, L.; Kostić, O.; Jarić, S.; Stevanović, B.; Mitrović, M.; Pavlović, P. Phytoremediation potential, photosynthetic and antioxidant response to arsenic-induced stress of Dactylis glomerata L. sown on fly ash deposits. Plants 2020, 9, 657. [CrossRef]

84. Pavlović, P.; Mitrović, M.; Djurdjević, L. An ecophysiological study of plants growing on the fly ash deposits from the “Nikola Tesla-A" thermal power station in Serbia. Environ. Manag. 2004, 33, 654-663. [CrossRef] [PubMed]

85. Mitrović, M.; Pavlović, P.; Lakušić, D.; Stevanović, B.; Djurdjević, L.; Kostić, O.; Gajić, G. The potential of Festuca rubra and Calamagrostis epigejos for the revegetation on fly ash deposits. Sci. Total Environ. 2008, 72, 1090-1101. [CrossRef] [PubMed]

86. Gajić, G.; Pavlović, P.; Kostić, O.; Jarić, S.; Djurdjević, L.; Pavlović, D.; Mitrović, M. Ecophysiological and biochemical traits of three herbaceous plants growing of the disposed coal combustion fly ash of different weathering stage. Arch. Biol. Sci. 2013, 65, 1651-1667. [CrossRef]

87. Gajić, G.; Djurdjević, L.; Kostić, O.; Jarić, S.; Mitrović, M.; Stevanović, B.; Pavlović, P. Assessment of the phytoremediation potential and an adaptive response of Festuca rubra L. sown on fly ash deposits: Native grass has a pivotal role in ecorestoration management. Ecol. Eng. 2016, 93, 250-261. [CrossRef]

88. Żołnierz, L.; Weber, J.; Gilewska, M.; Straczyńska, S.; Pruchniewicz, D. The spontaneous development of understory vegetation on reclaimed and afforested post-mine excavation filled with fly ash. Catena 2016, 136, 84-90. [CrossRef]

89. Burducea, M.; Lobiuc, A.; Asandulesa, M.; Zaltariov, M.-F.; Burducea, I.; Popescu, S.M.; Zheljazkov, V.D. Effects of sewage sludge amendments on the growth and physiology of sweet basil. Agronomy 2019, 9, 548. [CrossRef]

90. Pengcheng, G.; Xinbao, T.; Yanan, T.; Yingxu, C. Application of sewage sludge compost on highway embankments. J. Waste Manag. 2008, 28, 1630-1636. [CrossRef] [PubMed]

91. Mazen, A.; Faheed, F.A.; Ahmed, A.F. Study of potential impacts of using sewage sludge in the amendment of desert reclaimed soil on wheat and jews mallow plants. Braz. Arch. Biol. Technol. 2010, 53, 917-930. [CrossRef]

92. Zhang, X.; Huang, G.; Bian, X.; Zhao, Q. Effects of root interaction and nitrogen fertilization on the chlorophyll content, root activity, photosynthetic characteristics of intercropped soybean and microbial quantity in the rhizosphere. Plant. Soil Environ. 2013, 59, 80-88. [CrossRef]

93. Martinez, L.J.; Ramos, M.A. Estimation of chlorophyll concentration in maize using spectral reflectance. Int. Arch. Photog. Remote Sens. Spat. Inf. Sci. 2015, 40, 65-71. [CrossRef]

94. Herrmann, I.; Karnieli, A.; Bonfil, D.J.; Cohen, Y.; Alchanatis, V. SWIR-based spectral indices for assessing nitrogen content in potato fields. Int. J. Remote Sens. 2010, 31, 5127-5143. [CrossRef]

95. Homolová, L.; Malenovský, Z.; Clevers, J.G.P.W.; García-Santos, G.; Schaepman, M.E. Review of optical-based remote sensing for plant trait mapping. Ecol. Complex. 2013, 15, 1-16. [CrossRef]

96. Camino, C.; González-Dugo, V.; Hernández, P.; Sillero, J.C.; Zarco-Tejada, P.J. Improved nitrogen retrievals with airborne-derived fluorescence and plant traits quantified from VNIR-SWIR hyperspectral imagery in the context of precision agriculture. Int. J. Appl. Earth Obs. Geoinf. 2018, 70, 105-117. [CrossRef]

97. Corp, L.A.; McMurtrey, J.E.; Middleton, E.M.; Mulchi, C.L.; Chappelle, E.W.; Daughtry, C.S.T. Fluorescence sensing systems: In vivo detection of biophysical variations in field corn due to nitrogen supply. Remote Sens. Environ. 2003, 86, 470-479. [CrossRef]

98. Schächtl, J.; Huber, G.; Maidl, F.-X.; Sticksel, E.; Schulz, J.; Haschberger, P. Laser induced chlorophyll fluorescence measurements for detecting the nitrogen status of wheat (Triticum aestivum L.) canopies. Precis. Agric. 2005, 6, 143-156. [CrossRef]

99. Cendrero-Mateo, M.P.; Moran, M.S.; Papuga, S.A.; Thorp, K.R.; Alonso, L.; Moreno, J.; Campos, G.P.; Rascher, U.; Wang, G. Plant chlorophyll fluorescence: Active and passive measurements at canopy and leaf scales with different nitrogen treatments. J. Exp. Bot. 2016, 67, 275-286. [CrossRef] [PubMed]

100. Shool, A.; Shamshiri, M.H. Effect of arbuscular mycorrhizal fungi and Pseudomonas fluorescence on chlorophyll fluorescence and photosynthetic pigments of pistachio seedlings (Pistacia vera cv. Qazvini) under four water regimes. Eur. J. Exp. Biol. 2014, 4, 246-252.

101. Jastrzębska, M.; Kostrzewska, M.K. Using an environment-friendly fertiliser from sewage sludge ash with the addition of Bacillus megaterium. Minerals 2019, 9, 423. [CrossRef]

102. Kalaji, M.H.; Schanskser, G.; Ladle, R.J.; Goltsev, V.; Bosak, K.; Allakhverdiev, S.I.; Brestic, M.; Bussotti, F.; Calatayud, A.; Dabrowski, P.; et al. Frequently asked questions about chlorophyll fluorescence: Practical issues. Photosynth. Res. 2014, 122, 121-158. [CrossRef] [PubMed]

103. Tan, L.P.; He, J.; Lee, S.K. Physiological responses of certain ornamental plants to sludge and artificial topsoils derived from flyash, sludge, and rengam series subsoil. J. Plant. Nutr. 1999, 22, 987-999. [CrossRef] 
104. Badek, B.; Romanowska-Duda, Z.; Grzesik, M.; Kuras, A. Physiological markers for assessing germinability of Lycopersicon esculentum seeds primed by environment-friendly methods. Pol. J. Environ. Stud. 2016, 25, 1831-1838. [CrossRef]

105. Badek, B.; Romanowska-Duda, Z.; Grzesik, M.; van Dujin, B. Rapid evaluation of germinability of primed china aster (Callistephus chinensis Ness.) seeds with physiological and biochemical markers. J. Hort. Res. 2014, 22, 5-18. [CrossRef]

106. Romanowska-Duda, Z.; Grzesik, M.; Kalaji, H.M. Phytotoxkit test in growth assessment of corn as an energy plant fertilized with sewage sludge. Environ. Prot. Eng. 2010, 36, 73-81. 